\title{
Superconducting Magnetic Energy Storage (SMES) Program January 1-December 31, 1981
}


The four most recent reports in this series, unclassified, are LA-7294-PR, LA-7701-PR, LA-8199-PR, and LA-8777-PR.

This work was supported by the US Department of Energy, Division of Power Delivery and Division of Energy Storage Technology (Office of Energy Systems Research).

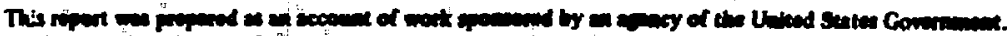

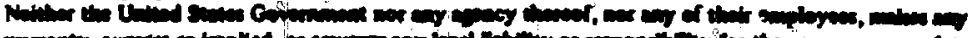

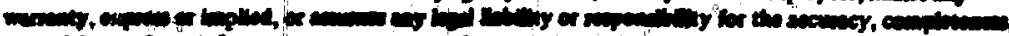

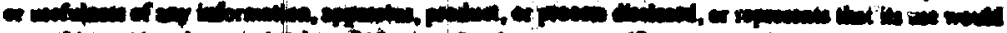

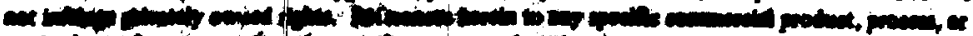

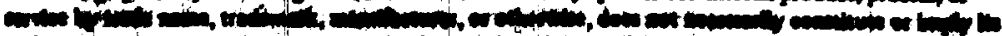

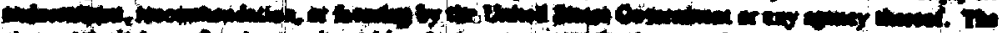

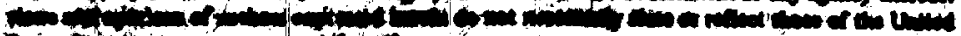


SUPERCONDUCTING MAGNETIC ENERGY STORAGF (SMES) PROGRAM

\author{
January 1--December 31, 1981 \\ Complied by \\ John D. Rugers
}

\begin{abstract}
Work reported is on the development of a $30 \mathrm{MI}$ superconducting magnettc energy storage (SMF.S) un 1 t fur use by the Bunneville Power Adminiatration (BPA) to stabllize power usillations on their Pacific AC Intertie. The $30 \mathrm{MJ}$ superconducting cotl manufacture was completed. Design of the selsmic muuting of the coll to the noncundicting dewar lid and a concrete fuundation is complete. Parts for the seismic muunting are delivered and coll mounting has started. Yanufacture of the nonconducting dewar has started. The stainless steel dewar lid has been made, and a secund lower cust aluminum lid has been ordered fur testing the dewar. Design of the $5 \mathrm{kA}$ vapur couled leads is complete and parts are being ordered. The refigeratur was repaired and tested for the first time at Los Alamus. The heat rejection system, the high pressure gas recuvery system, the converter, and parts of the refrigeratur have all been operated with computer control. The uninterruptible power supply was delivered and successfully tested. The damaged 6 MVA transfurmer was repalred and delivered to the Tacoma Substation. Detalled translent voltage analyses of the $30 \mathrm{MJ}$ coil and related protective circuit were completed. The control and data acquisition system hariware is $95 \%$ complete and software is $7 n$ to $87 \%$ complete. A health, safety, and envirunmental study of the BPA SMES installation was completed. $B P A$ and the Los Alamos National Laboratory have established a schedule for Installation and operation of the SMES unit at the Tacuma Substation.
\end{abstract}

The superconducting application VAR (SAVAR) contrul study indicated a low ecunomic advantage and the SAVAR program was terminated.

An economic and technological evaluation of a superconducting fault current 1 imiter (SFCL) was completed and the results are reported. 


\section{SUMMARY}

The goal of the Los Alamos National Laboratory's SMES program is to develop electrical un!ts to store energy in a magnetic field around a coll or iriductor. The magnetic fleld is created by an electric current flowing in a conductor that is in the superconducting state. Many materlais, such as nioblum-titanfum, lose their resistance to electric currents, that is, become superconducting at low temperatures. Electrical utllitles can use 1 to 10 GWh SMES units to meet diurnal varlations in consumer power demand. During the night, when consumption Is low, generators can supply energy to the unit. During the day, when demand is high, energy can be drawn from the SMES unit. In another application, smaller $30 \mathrm{MJ}(8.3 \mathrm{kWh})$ SMES units can be used to damp out the short term power uscillations that, in complex electrical grids, sometimes $11 \mathrm{mit}$ maximum power transmission.

This report describes the prugress made in the design and hardware development of the $30 \mathrm{MJ}$ stabilizing SMES unit. The components that must be considered for buth systems are the coll; the dewar, which w111 contain the coll and liquid hellum to cool it to the superconducting state; the cryogenic equipment to make 11quid helium and keep it cold; the electrical equipment to connect the coll to the power grid; and, finally, the monitur and control equipment to control the charge and discharge of the coll.

The $30 \mathrm{MJ}$ superconducting coll, designed and manufactured by General Atumic Company (GA), was completed.

Because the power oscillations to be damped on the Bonneville Power Administration (BPA) Pacific AC Intertie occur at a frequency of $0.35 \mathrm{~Hz}$, the SMES coll must be contained in a nonconducting dewar to avold coupling losses which would occur with a conventional metal dewar. A design and manufacturing contract was rlaced with Fiberglas Design to make the epoxy fiberglass dewar and manufacture has started. The stainless steel lid for the dewar was deslgned by the Los liamus National Laboratory, manufactured by Monarch Machlne, and delivered to GA for seismic mounting of the $30 \mathrm{MJ}$ coll to the dewar 11 .

The seismic mounting design of the $30 \mathrm{MJ}$ coll to the dewar $11 \mathrm{~d}$ and external structural beams and concrete foundation was done by Los Alamos and given to GA for the actual coll mounting. Mounting parts, dewar 11d, and the beams have all been supplied by Los Alamos. The foundation drawings were reviewed by BPA and modifled in keeping with their recommendat lons.

The detalled deslgn of the $5 \mathrm{kA}$ vapor cooled leads for conducting current from $300 \mathrm{~K}$ at the dewar $11 \mathrm{~d}$ to the superconducting coll at $4.5 \mathrm{~K}$ in $11 \mathrm{lqu}$ (d helium is complete and parts are being ordered.

The Model 2800 refrigerator delivered by Koch Process Industrles, formerly CTI-Cryogenics, was damaged during shipment to Los Alamos in 1980, was returned to the manufacturer and repalred, shipped again to Los Alamos, and finally operated at Los Alamos. A number of defletencles still exist and are belng eliminated.

The gas recovery system, to store excess hellum in a raflway tank car at the Tacoma Substation, was completed and successfully operated with computer control. 
The heat rejection system, an ethylene glycol-water cooling heat dump, was operated in conjunction with the refrigerator and was successfully computer controlled.

The converter, the electrical a.c.-d.c. thyristor contrulled interface between the $30 \mathrm{MJ}$ SMES coll and the BPA bus, was completely tested with both reslstive and Inductlve loads. The converter was also computer operated with a BPA simulated demand signal.

The $5 \mathrm{kVA}$ uninterruptible power supply, to be the cuntrol system auxtliary power source from a BPA battery supply, was successfully tested.

The 6 MVA transformer, which goes from the BPA bus $t$ ) the converter and was damaged in transit in 1980, was repaired, tested, and shipped to the Tacoma Substation.

Concern has existed abuut pussible voltage enhancement from excitation of the natural frequencies of the $30 \mathrm{MJ}$ coil from transient voltages. nf particular interest has been the possible high vultage switching pulse which may vccur with the stray inductance of the protective dump circutt. The dump circult and distrlbuted capacitance of the coll were analyzed in detall. Effects are marginal and protectlve surge arresters are being considered.

The 30 MJ SMES system is to be computer controlled by microwave 1 ink from the BPA Portland area contrul center to the Tacoma Substation. The computer hardware $1 \mathrm{~s} 95 \%$ complete and software is 70 to $80 \%$ complete. The majur accomplishments in the SMES control and data acquisition system include (1) operation of several SNES subsystems from the supervisory computer, (2) completion of contrul speciflcations for several subsystems, (3) mudiflcatiun of contrul circults in severa! subsystems to increase the effectiveness of computer contrul, (4) completion of the design for the supervisory software structure, (5) completions of the design, coding, and check of the a.c.-d.c. converter control software with the hardware, (6) completion of the deslgn, coding, and check of the operator display software with the hardware, (7) design and cuding of the control software for the high pressure gas recovery subsystem, (8) completion of the software executed by the slave computers, and ( 9 ) change of operating system frum RT-11 to RSX-1IM. The a.c.-d.c. converter, hent rejection, high pressure gas recovery, and portions of the refrigerator subsystems have been operated through the supervisory and slave computers. This accomplishment provides verification for the system cabling, signal conditioners, computer hardware, many programs in the supervisory and slave computers, and the supervisor data base. The control description of the los Alamos-BPA computer interface subsystem has been sent to BPA for thelr review.

The environmental effect of the 30 MJ BPA SMES system is quite $11 \mathrm{mited}$. Consequently, the environmental concerns were treated in a "Health, Safety, and Envirunmenta1 Remark."

BPA and Los Alamos have established a schedule for installation and operation of the $30 \mathrm{MJ}$ SMES system. To do this, BPA agreed to alter thelr research and development program and fund commltment. 
The superconducting application VAR (SAVAR) control program undertuok a conceptual design study and cost comparisun. The result was that the competitive advantage was small and the program was terminated.

Power transmission systems can be built more economically if fault currents can be ilmited. Different concepts of fault current limiter design have been proposed over recent years. Superconducting fault current ilmiter (SFCL) concepts involving a diode bridge as proposed by Westinghouse Electric Corporation and also as modified by Los Alamos with an SCR bridge have been studied for both economic and technological evaluation. The results are included herein.

II . BONNEUILLE POWER ADMINISTRATION STABILIZING SMES UNIT

A. Int roduction

The Pacific Northwest and southern Californla are part of the Western li.S. Power System and are connected by two $500 \mathrm{kV}$, a.c. power transmission 11 nes, collectively referred to as the Pacific AC Intertie, and une $\pm 400 \mathrm{kV} \mathrm{d.c.}$ transmission line, the Pacific HVDC Intertle. The two a.c. llites have a thermal rating of $3500 \mathrm{MW}$, and the d.c. Itne has a rating of $1440 \mathrm{MW}$.

The stabllity of the Western Power System is affected by relative weakness of the the pruvided by the $905 \mathrm{mile}$ long Paciflc AC Intertle. In fact, studies made before energization of the Paciflc AC Intertie showed that negatively damped osclilations with a frequency of about $20 \mathrm{cpm}$ were likely to occur. In 1974 negatively damped oscillations with a frequency of $21 \mathrm{cpm}(0.35 \mathrm{~Hz})$ were ubserved. The peak to peak uscillation on the Paciflc AC Intertie was about $300 \mathrm{MW}$. Subsequent to these Instabilities, the BPA Installed equipment on the HVDC Intertie to use as a power source to modulate the power flow in the HVAC Intertle as a means of damplng the oscillations. The maximum possible power modulation is $\pm 40 \mathrm{MW}$. The modilation has increased the stabllity $11 \mathrm{mlt}$ of the Pacific $A C$ Intertie from about $2100 \mathrm{MW}$ to $2500 \mathrm{MW}$ whenever the HVDC Intertie is operating. However, the HVDC Intertie does not operate contlnuously. The line avallability is $89.5 \%$, and the southern terminal was down for slx months a: one time as a result of earthquake damage. A back-up stabilizing system coul: be used. Late In 1975, representatives of BPA and Los Alamos developed the concept of Installing a small SMES unit for the purpose of provfding system damping similar to that now avaliable by modulation of the intertie. The small. SMES unit has been developed tu a very advanced hardware stage with component testing conducted at the Los Alamos National laburatury. The unit is scheduled for Installation frum 6/82 through $9 / 82$ with experimental and utility operation to run from $10 / 82$ through $9 / 83$ with a decision to be made in $9 / 83$ by BPA to ut $111 z e$ the unit as a permanent part of their electrlc power grid.

B. Superconducting Coll Design and Manufacture Coll (Henke, Rogers, Schermer; General Atomic Co. staff)

A $30 \mathrm{MJ}$ BPA SMES coll to store energy was designed and manufacture started in 1980. The coll was completed in 1981 and design was finished for seismlc mounting of the coll to the dewar 11d. Contractural arrangements have heen made with GA to have the coll mounted. 
Winding and stacking of the indlvidual pancake colls was completed by mid February 1981. Assembly of the full $30 \mathrm{MJ}$ coll was completed in early July, one month ahead of schedule and considerably below the contract cust. Thruughout this perlod, procedures were under continuous review by los Alamus representatives and GA staff. On February 3, 1981, a team of flve outslde experts was invited to inspect the nearly complete coll. This revlew led to the performance of several mechanical and high voltage tests and to some minor modifications in materlals and prucedures.

The separate pancake coils as wound were out-of-round and tended to warp out-of-plane. All reviewers felt that such irregularities were nut serfous provided they did not interfere with assembly. During stacking, the pancake colls were forced to be round by jacks, and the coll inner support $r$ lngs were fastened together with scroll pins. Pinning also increases the inter pancake shear capability to resist the load required fur selsmic cunsiderations. After assembly, clamps were used to compress the full coll to the theoretical designed helght to remove any residual effect of warping. Before cunstruction began there was some cuncern that pussible creep in the plastic mandrel or conductir Insulating tape could lead to relaxation of the winding preload. Accisdinglv, witness marks were made in the first two particake colls to be wound. These marks showed zero creep after four months. Numerous minur variances, as fullv documented in the final report, from what later became standard prucedure occurred in the first few pancake colls. Althuugh nune of these were considered serlous enough to require rewinding the pancake colls, alterations were made wherever phystcally posstble.

A stainless steel strap is co-wound with the conductur and provides the force support. Questions were raised regarding the strength of the structure that terminates the outer end of the strap. GA fabricated a model and tested it mechanlcally. The assembly holds at least twice as much force as required in service and falls by slow elastic ylelding. One of the straps was partlv severed, by accident, In the outer termination region. An addittonal turn uf strap was applied to this one pancake coll to provide extra support for the cut reglon that, by calculation, would probably still support the requlred force without any reinfurcement.

Most of the modiflcations made were to the electrical and mechanlial aspects of the superconducting cable joints. Insufficient high voltage withstand capability was corrected in part by replacing aluminum support hlocks with NEMA grade LF linen phenulic. The linen phenolic, being hydruscopic, tracks badly along the fiber direction. Phenolic parts were redesigned to avold this tracking, whlch interfered with testing but would not occur at low temperature during operation. All linen phenolic parts were sealed with a wash coat of epoxy as a further precaution. Mechanically, each juint was a special case and required individual hand fitting of spectal fixtures to provide adequate support to all second level superconducting cables. Ti.e actual joint soldering, performed with an electrically heated mold, was quite readily accomplished.

Care was taken during assembly of the entire coll to prevent debris from entering the structure. After completion, the coll was thoroughly vacuumed and was covered with plastic to await mounting. 
C. Nonconducting Dewar (Rogers, Schermer; Bennett, Q-13)

Because the coll cycles continuously at a frequency of $0.35 \mathrm{~Hz}$, the Inner liquid hellum vessel must be made of glass refnforced epoxy to avold eddy current heating which would occur in a metal walled dewar. The outer roomtemperature vessel can be constructed either of a sultable plastic or of 300 series stainless steel. Further, the vessels can be assembled with either demountable or permanent seals. RFQs were issued covering varlous combinations of these options for the vessels. Five responses were recelved to bulld a plastic dewar and one response for a roum temperature stainless steel outer dewar vessel. The steel vessel was rejected, partly to avoid prublems with pulsating loads and nununiform potential gradients and partly io avold the problem of a vacuum seal between the Inner and outer vessels. Four vendors bid on the option with two plastic vessels assembled with a permanent seal. The contract was awarded to Fiberglas Deslgn, Benlcla, CA, on the hasis of technical merit, experience, and cost. Lengthy contract negotiations ensued, due principally to the accounting practices and records of this very small company. The contract was placed and actual mold construction began in November 1981 .

The Inner vessel will be fabricated using hand lay-up techniques. Each day's epoxy layer will be cured at a slightly elevated temperature, roughly $80^{\circ} \mathrm{C}$, overnlght by sealing and warming the lay-up roum. The outer vessel will be fabricated from polyester resin and chopped glass fiber and will be stiffened against buckling by circumferential ribs.

The vessel lid is a major structural element. Selsmic forces must he transmited through the material to the coll mounting structure to avold numerous penetrations to accommodate these structural elements. A G-10 epoxy $f 1$ berglass lid of the size required would have to be laminated from numerous small segments of sheet material, would be more difficult to machine than steel, and would be more expenslve. For these reasons a 1 l/2 in. thlck stainless steel lid was chosen with whatever high voltage insulation prublems resulted. The 11d was designed at the Los Alamus National Lahoratory and fabricated by Monarch Machine, Los Angeles. Originally, the steel lid was tu have served as a template for drilling the dewar flange bolt holes and as a cover during dewar testing prior to being sent to GA for coll mounting. The lung telay in dewar procurement no longer permits this schedule. Instead, a $11 / 41 \mathrm{n}$. thick aluminum lid has been ordered to serve as template and test cover. In addition, this lid will be left in place during shippling as it stiffens the vessel flanges and makes handling the vessel far easler and safer.

The dewar flange design continued in 1981 with two finite element representations. To investigate the $11 \mathrm{~d}$ closure seal, the bult design, and the stresses in the flanges for the $30 \mathrm{MJ}$ coll SMES dewar, two finlte element models of an upper portion of the vessel were constructed with the finite element computer code, ADINA.l The first model, shown In FIg. l, was a coarse grid, axisymetric model. The purpose of this model was to determine the stresses under the operating condition of $15 \mathrm{psig}(103 \mathrm{kPa})$ and a fault condition of $30 \mathrm{ps} 1 \mathrm{~g}$ ( $207 \mathrm{kPa}$ ) in the 11d near the flanges so a detalled model of these reglons could be studled. The detalled model, shown in Fig. 2, applled the shear and moment to the $11 \mathrm{~d}$ as determined from the whole model of Fig. 1 at the equivalent section of the 11d. The destgn finally adopted uses a 4 in. wide by 2 in. thlck flange on the epoxy fiberglass Inner vessel with a $1 / 2$ in. by $1 / 2$ in. fillet region at the juncture of the 1 in. thick vessel wall. Maximum 


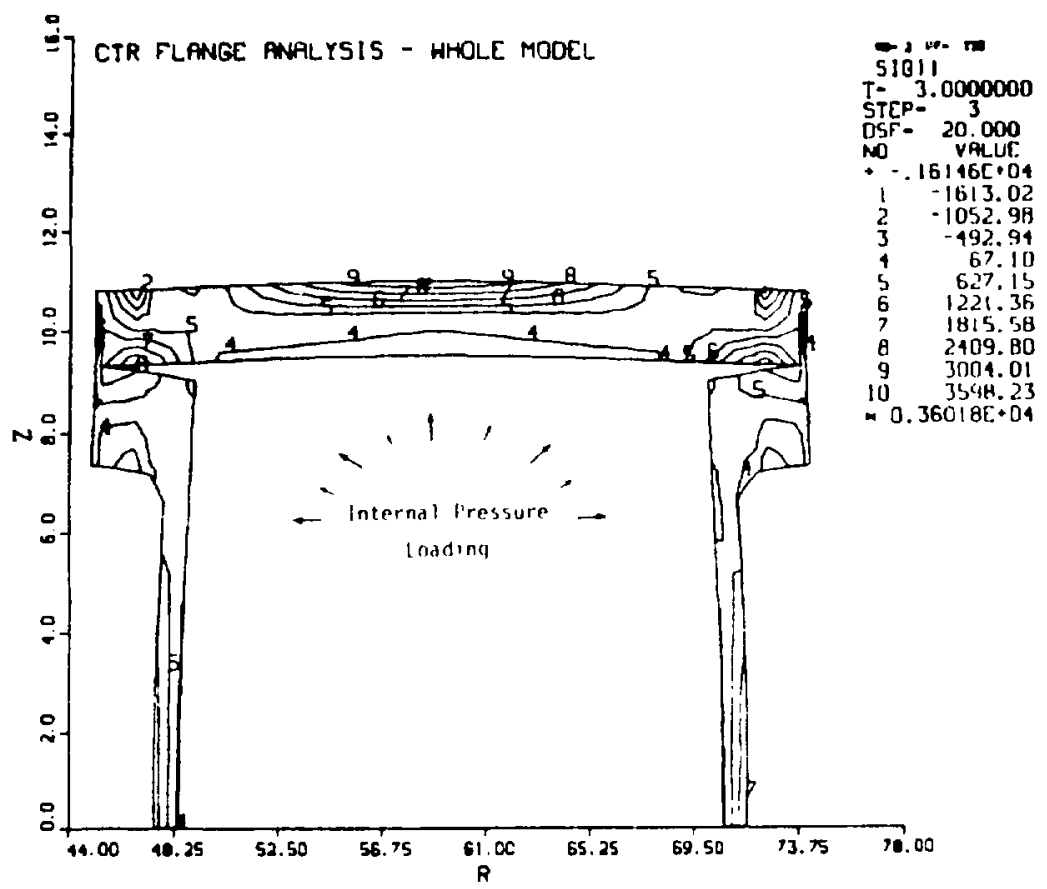

F1g. 1. Maximum principal stresses for vessel and $11 d$ under Internal pressure - coarse grid.

stresses ir the plastic under normal operating conditions are below the $5 \mathrm{ksi}$ (34 MPa) creep $11 \mathrm{~m}$ ltation for this material. The vessel, as finally designed, tapers from $1 \mathrm{in}$. at $10 \mathrm{in}$. below the flange to a $11 / 2 \mathrm{in}$. thick wall at the juncture. Great care 1 s being exercised in muld construction to pruduce a flange face flat and smooth enough to eliminate machining.

The flange and wall are very flexible in bending and, under applled pressure, rotate unt 11 restrained by the $11 d$ or bolts. This is a qualitatively different situation than found for a metal vessel. In addition, it creates difficulty in computer mudeling. To control the rotation, the lid should not be undercut; rather, the $11 \mathrm{~d}$ and flange must contact along their outer edges. When this occurs, the displacement brtween the $11 d$ and flange face at the $0-r i n g s$ is only $0.006 \mathrm{in}$. $(0.2 \mathrm{~mm})$ under iormal operating conditions.

The 1 in. flange bolts undergo fafrly high stresses, $18 \mathrm{ks} 1$ (124 MPa) tension and $42 \mathrm{ksl}(288 \mathrm{MPa})$ bending at $30 \mathrm{psig}$ internal pressure. ASTM A-325 bolts of weathering steel have been specifled for the application.

The dewar vendor has prepared a detalled drawing of the inner vessel zeometry. The design has been subjected to finite element analysis, with particular attention pald to stress, displacement, and possible buckilng in the vicinity of the torispherical bottom end. The pressure history of the dewar under various assumed faults was calculated to size the rellef vent and rupture disks; to check that the calculated dewar bucking pressure, 35 psig, is 


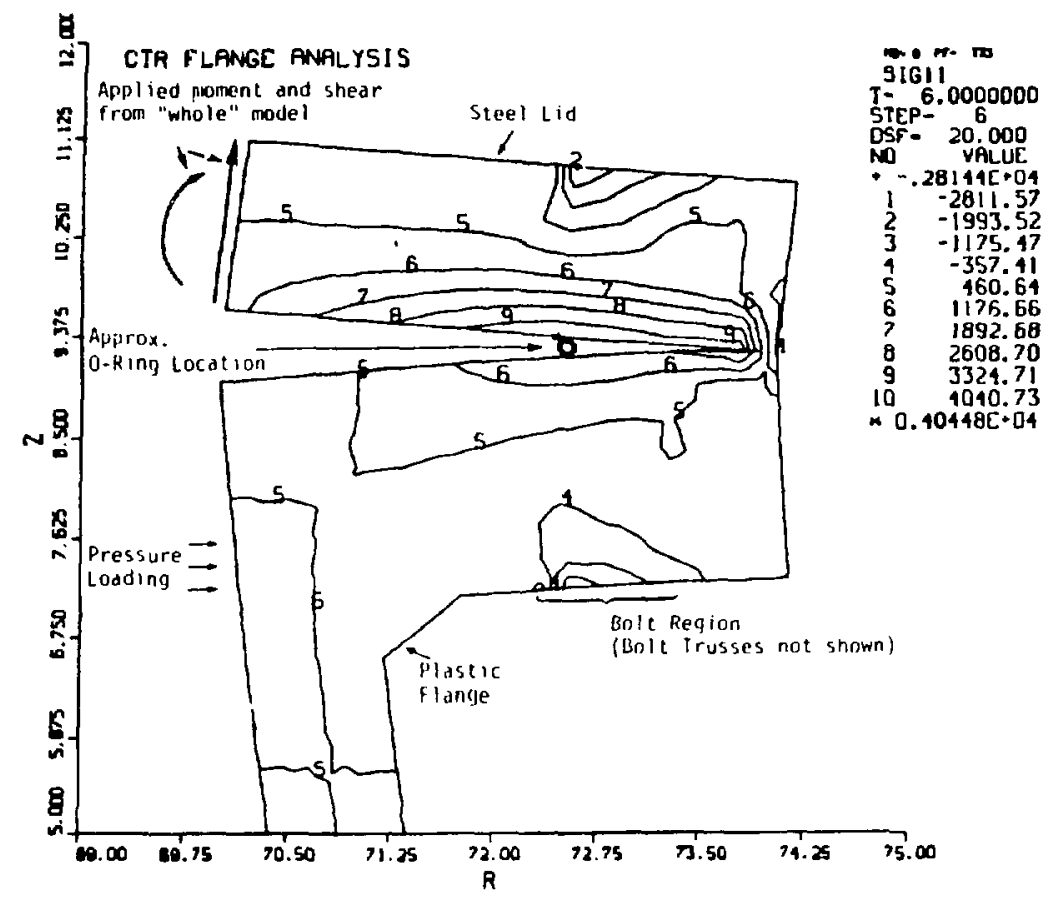

F1g. 2. Maximum pilnclpa1 stress in right hand flange from ADINA model with displacements exaggerated by a factor of 20 .

adequate; and to ald in preparing a safety analysis of the system. Coll shutdowns, triggeted by quench detection, low 11 quid hellum level, cr hellum pressure rise, will $1 \mathrm{~lm} 1 \mathrm{t}$ the dewar pressure to 9 to $10 \mathrm{psig}$ and will not even $11 \mathrm{ft}$ the rellef vents, which w111 be set for $18 \mathrm{ps} 1 \mathrm{~g}$. If all these safetles fall or if the vacuum falls catastrophically, the pressure will rise to 23 psig and the two $6 \mathrm{in}$. rupture disks will blow. Vacuum fallure deposits roughly $60 \mathrm{~kW}$ in the hellum while a fully normal coll deposits $600 \mathrm{~kW}$. At $600 \mathrm{~kW}$, disk rupture occurs in $10 \mathrm{~s}$. The pressure continues to rise another 1.1 ps 1 while the warm gas column from the upper section of the vessel vents, which takes 0.3 s. Even if the fully normal coll remains on, the pressure then drops rapldiy to 24 psig and continues to fall and then falls for the next 10 to $20 \mathrm{~s}$ as the hellum vents. The disks are also adequate to protect the dewar under any concelvable accident involving room temperature hellum gas during system cleanup or startup. Rellef vents add 11 ttle to system safety. They have been sized to handle normal dewar boll-off in case varlous valves are accidently closed.

Superinsulation techniques w111 rely heavily on englneering performed for other large magnet projects, In particular ISABELLE at the Brookhaven National Laboratory. Double aluminized Mylar* will be striped to disrupt eddy current 
loops and then laid in batts ten layers thick with Nexus* cluth separators. Nexus, a non-woven polyester product, is not hydroscoplc and creates less vacuum pumpling load than previously used nylon separators. The batts wlll be held together with nylon clothing tag fasteners, tapered to fit properly over the cured vessel end, and set in place flange to flange on the vessel. Fiectric seissors will be used for eutting and shaplng batts. Installation will pruceed azlmuthally around the vessel. Succeding layers of batts will be artanged to overlap joints in lower layers until a total or 100 layers of superinsulation are applied. The batts will be supported at their upper edge with Nylon grommets and braided glass lacing cord.

Vacuum pumpdown is greatly facilitated if the Mylar is perforated, with 1/16 in. holes on $3 / 8 \mathrm{in.} \mathrm{centers.} \mathrm{Perforation,} \mathrm{however,} \mathrm{is} \mathrm{a} \mathrm{very} \mathrm{expensive}$ process according to the only bld obtained. This problem has not been solvel.

D. Coll and Dewar Structural Suppcrt (Henke, Schermer; Ellard, ENG-2; Bennet, But lct, Q-13; General Atomic Co. staff)

Coil support presented an unusual problem. At Tacoma, WA, the system will be installed in a Zone $C$ selsmic region, with design accelerations of $0.24 \mathrm{~g}$ horlzontal and $0.16 \mathrm{~g}$ vertical. Large magnets are usually enclused $\mathrm{fn}$ a welded metal dewar that can be routinely supported in a variety of ways. Permanent encapsulation of the $30 \mathrm{MJ}$ coil in its epoxy fiberglass dewar, whleh must be free of seals or jolnts to avold helium leaks is deemed inapproprlate. Further, the ASME Unfired Pressure Vesse1 Code recommends agalnst using a plastic vesse1 as a structural element. Therefore, a stiff support system was designed to suspend the coil freely witin an open mouth helium vessel. Computations were performed based on the response spectra technique, and finite element codes end anaiysis rules were developed for nuclear reactor systems. One sixth of the support system is shown in Fig. 3. The shear pane1, a $3 / 8$ in. thick fiate of G-10 CR, resists a lateral load of up to $18,0001 \mathrm{~b}$. The panel is mounted to transmit low vertical loads to the coil clamping structure. Vertical loads, which vary between $19,0001 \mathrm{~b}$ tenston and $70001 \mathrm{~b}$ compression, are taken by a stafnless steel support tube with ball jolnt ends to avoid bending. Coil inotion is less than $7.060 \mathrm{jn}$. In any direction. All loads are transmitted thrugh the $11 / 2$ in. thick stainlese steel dewar $11 d$ and $s t x$ steel support beams tu concrete columns.

Partial decoupling of loads in the vertical trusses from lateral motion was accomplished by using kinematic joints on both ends of the trusses and un the tops of the shear panels. Such decoupling is necessary to maintain the frlctional restraint in the $30 \mathrm{MJ}$ coll design. However, the amount of coupling between the vercical and lateral coll motion is still significant enough that care was exercised in selecting the stiffness of the supporting vertical trusses and shear panels. Making the shear panels quite stiff considerably lowered the forces in the trusses but produced prohlbitlve loads on the panels themselves. Several partial analyses to obtain modal participation factors were performed to determine an optimum design. A shear panel thickness of $0.375 \mathrm{in}$. (0.95 cm) was finally selected to distribute the loads appropriately among the components. The relative displacements between the coil and dewar and absolute displacements laterally along the dewar cover where the magnet vertical trusses attach were calculated. The results are summarized in Table I. 


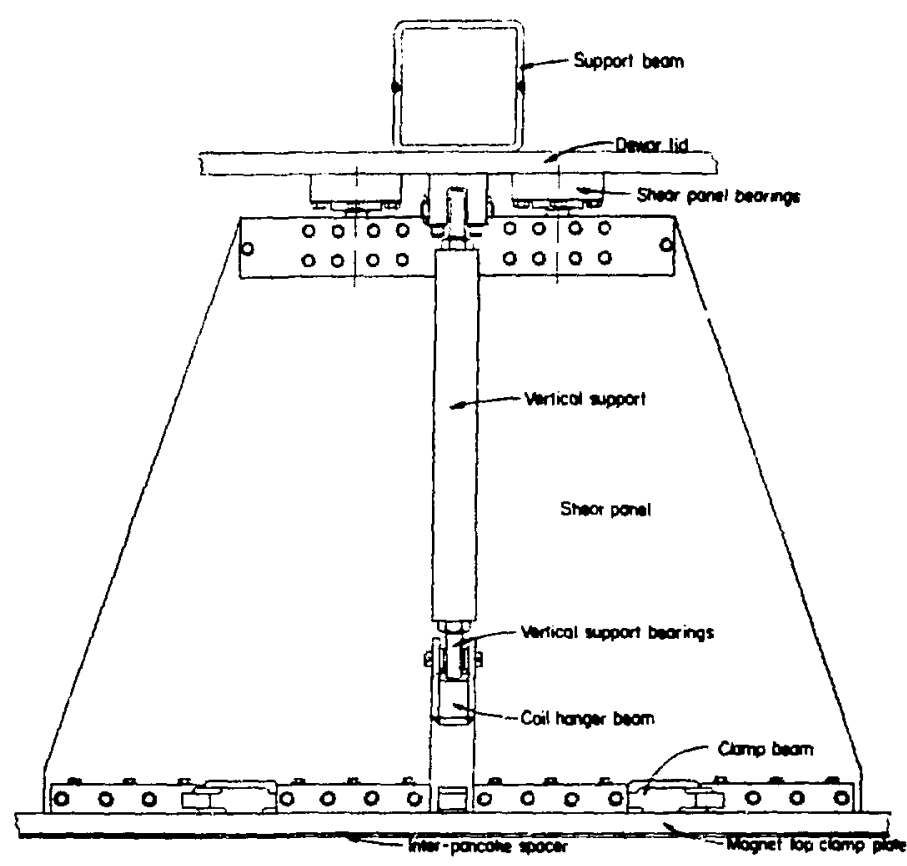

FIg. 3. One $60^{\circ}$ segment of the coll support system; vertical section normal to radius.

TABLE I

DISPLACEMENTS OF MAGNET SUPPORT SYSTEM

FROM A 0.25 g EARTHQUAKE

Magnet displacement relative to dewar

$z$ (vertical) $0.044 \mathrm{in}$.

$x$ (latera1) $0.053 \mathrm{in}$.

$y$ (lateral) $0.063 \mathrm{in}$.

Maxinum vertical displacenent of dewar cover

z (vertical) $0.0043 \mathrm{in}$.

A11 the support ellements have been fabrlcated and recelved. Under Phase III of the $30 \mathrm{MJ}$ coll contsact, GA will perform the support mounting and will equip the dewar 11d with aI1 necessary baffles, Instrumentation, and protective devices. The coll will be shipped from San Diego to Tacoma with all these conponents in place.

Foundation design was done by the laboratory group, ENG-2. At thelr request, a soll sample analysis was performed at the proposed coll location in the Tacoma, WA substation of BPA. Core samples revealed a five foot layer of 
peat below a ten foot surface layer of sand and gravel. Calculations, based upon compaction tests, indicated that the concrete structure would settle $10 \mathrm{in}$. during the first year. Although the settling would he acceptable if lt were uniform, a $2^{\circ}$ tilt would make coll and dewar installatim imposstble. Fintshed foundation drawings call for a $2 \mathrm{ft}$ thlck monolithli cuncrete slah supported in pilings. Reinforcement for the slab and wil support columns usios ther relnforced pulyester and scalniess sceel relnforcling bar as much as possible to avold coupling forces to the cotl in the dewar from the fringe ragnetic fleld.

E. Hellum Vapor Cooled 5 kA Flectrlcal leads (Harkleruad, Harrlsum, Heit.., Schermer, Singletun)

Each of the ten superconductur subcables must equally carry a $i 50$ a share of the average d.c. coll current. As the serles reslistace varies ammg subcables from variatlons in jolnt resistance and ig the number of cold weits in

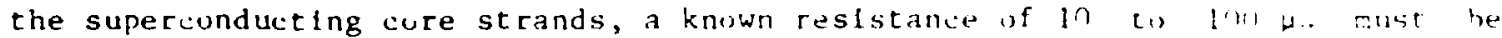
placed in serles whth each subcable. Pruviding each of the ten sibcatias with its own electricaily isolated power lead supplies the necessars resistane. The power leads for the $30 \mathrm{MJ}$ coll are mure compiax than tiuse fin urher sumerinducting magnets. Copper with a lin QRR has numerous advantages fur puwer loads compared to higher puricy cupper with a RRR in the fon to bit rain. leats formed of linpure copper have much better thermal stahllity as the whitil larger amounts of copper; they do not overheat as badly when silh jectin! (1) a higher wurent ur gas flow lower than the design value; did they hase d liwer heat leak when not carrving current. Materlal avaliabllity, at inas: in indli quantities, $1 \mathrm{~s}$ limfted almost ent: rely co phosphorus deoxidized iupper in the form of water service tubing. Accordingly. a reclsion was reached to furm the subcable leads from tubes of length and cross sectional area aproor: it" to til"

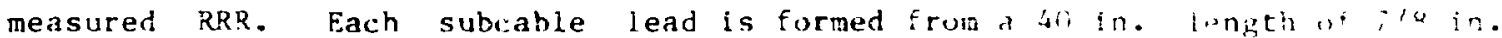
o.d. by $0.045 \mathrm{in}$. wall, type $\mathrm{L}$ tublng, made of copper alisy rib $12 \%$, so ialed "DHP" copper. A $1 / 2$ in. long sample was cut from each of 28 tubes, $\&$ to 12 it long. The samples were then fabrlcaled into rulled, annealed strlps iad resistivity measurements were performed. Sixteen tuhes with PRR in the range 7.14 to 8.18 were retalned for further processing; the renalinder were returied to stock.

Each tube was cleaned, anneaied in hydrugen, and flattened by pressi ik and rolling over a flat, brass nandrel to form a flat tube 1.312 in. witie with a $0.040 \mathrm{in.} \mathrm{Inside} \mathrm{channel} \mathrm{for} \mathrm{gas} \mathrm{flow.} \mathrm{The} \mathrm{flattening} \mathrm{process} \mathrm{increases} \mathrm{gas}$ velocity and improves the heat transfer.

The tubes $i l i$ be furnace brazed into a heavy cupper collector that forns the roum temperature electrical termination; and the entire assembl is then sealed into a G-10 epoxy flberglass box that forns the prinary eiectrical Insulation between the copper parts at high potential and the staliniess steel lid at ground potential. Parallel flow paths tend to be unstabie because, if one tube wams slightly, its flow Impedance Increases causing tt to warm st:li more. This instablilty is avolded by controlling the flow thruugh the tuhes with orlfices that are all attached to the sane massive copper structure at room temperature. Further, because ait the tubes are within the same G-I0 box, they are in thermal contact through the intervening gas space although they are electrlcally insulated frow each other. 
Detalled shop drawings for the lead have been completed. Bids have been sollcited for the G-10 parts, the bellows assembly, and for machining several complex cupper parts. In addition, some or all of the ruom temperature copper parts will be formed of free machining copper to reduce machining costs.

F. Cryogen1c System (Buteau, Dean, Harklervad, Schermer, Smith)

The cryugentc system for providing the liquid hellum to the $30 \mathrm{MJ}$ superconducting coil and gas storage is nearly cumplete. The traller munted major cumponents--refrigerator, heat rejection system, and high pressure gas recuvery system--have been delivered and undergone extensive testing.

1. Refrigerator. The refrigerator, delivered by Koch Processs Industries, formerly CTI-Cryogentcs, to Los Alamos in Septemuer 1980, was damaged in shipment. The refrigerator was returned to Koch for repalr. The repalrs were completed by June of 1981 and system performance was demonstrated at Koch's plant. A spectal contalner was made to hold the cold box heat exchanger assembly, which was shipped separately from the traller mounted refrigerator.

A Koch englneer was in Los Alamos during November I981 to particlpate in the fleld operation of the refrigerator and to train operating persunnel. About a week's work was requlred before operation began. The system was operated first as a liquefier at a rate of about $70 \mathrm{~L} / \mathrm{hr}$ and then as a refrigerator at $200 \mathrm{~W}$. Saveral contrul prublems were detected that need be remedied befure full compiter uperation begins. Subsystems of the refrlgerator, including the compressurs, have been uperated from the computer. A cost holdback is belng malntafned unt 1 the defects are repalred by los Alamos and a backcharge is intended to be made.

The refrigerator system was attached to the tratler mounted heat rejection system cooling tower, and flow thruugh the compressors was checked. Two of the screw compressur o11 aftercoolers were plugged. One was cleaned and unplugged at Los Alamos, the other was replaced by the manufacturer. The heat exchanger passages were blucked by calctum and magneslum carbunates preclpitated uut of Koch's cooling system. To accumplish the cleaning, mild acid solutions were circulated through plping. Cleaning solutions were also pumped directly thrugh the aftercoolers with one beconing unplugged and the other not.

One of the gas bearling turbine expanders was damaged durling the refrlgerator testing at Koch. The turbine was repalred at manufacturer's cost and delivered to Los Alamos.

2. Gas Recuvery System. The gas recovery system is to store in a rallway tank car at the BPA Tacoma Substation excessive hellum gas evolved frum the $30 \mathrm{MJ}$ coll dewar during upset operation or from intentional warming. The Corblin compressors of the high pressure gas recovery system were mounted with necessary piping and electrical wiring into a traller by a contractor. One of the two compressors lost 1 ts ofl prime during startup with damage occurring to a cylinder and piston. These parts were replaced and the system is operational. The gas recovery system and the heat rejection system have both been operated with computer contrul. 
1. Cunverter. (Buenig, Buteau, Grant, Harklervad, Loya, Ruppert, Smjth, Trude 11, Turner) right power terminal transitions thrugh the cunverter ruof were bullt and installed. The colverter terminals were cunnected by $4 / 0$ canles to the $3.25 \mathrm{MW}$ transfurmer terminals. A stalnless steel, $1 \mathrm{M}$ load durip was built and connected to the converter to be used for load testing. The heat rejection system was connected to the load dump to privide ethylene plycol-water coulant.

The converter was tested with ohmicinductlve load and all the scks were checked for current sharing. Durlng, the test, the converter a.c. supply voltage regulator developed a gruund fault. After bypassing the faulty device, the test was continued.

One high current SCR had to be replaced in one phase of a bridge to provtde better current sharlng. Different cests with the converter, which fnctuded the stmulation of fault conditions, show that the converter is conservativeiy designed and wil properly respond to different operating conditions expected for the SMES systen at Tacuma. The comverter was operated under cumputer control with BPA demand slgnal slmulation.

2. Uninterruptble Power Suppiy. (Boenig, Buteau, Turner) A 5 kyt Westinghouse uninterruptible power supply was ordered, recelved, and tested wilh a battery power source and meets specifications.

3. Transformers. (Boen18, Turner) The danged 6 dva transfurmer was repalred at the Nlagara Transfurmer plant in Buffalo, $X Y$; and the acceptance tests were witnessed by hos Mlamos personnel. The transformer was shipped to the Tacoma Substation where $t t$ is being stored. The 0.5 MVA auxiliary service transformer aiso was delivered to Tacoma.

4. Transient Voltage Analysls. (Andersun, Chowdhari) Previously repurted work indicated that the most serious translent voltage across the 30 M.J col. will he generated by the upening of the d.c. vacum circuit breaket in the protective dunp circuit of $\mathrm{FIg}$. 4. The analysts was extended by varying several parameters of the dump circuit to determine thelr effects on the transient voltage actuss the coll. Flgure 5 shows the effect of the self-inductance, $L_{2}$, and of the dump reslstor, $R$. Higher self-inductance of $R$ would increase both the pusitive and negative peaks of the transient voltage. The transient voltage is very sensitive to this parameter. Therefore, the dump resistor should be designed with the least possible self-inductance. Figure 6 shuws the effect of the counterpulse capacitor precharge voltage level, $V_{c}$. The higher this voltage is, the higher would be the positive peak of the transient voltage acruss the SMES coll; the negative peak of the transient voltage is insensitive to $V_{\text {. . In }}$ Fig. 6, the negative peak for $V_{c}=5 \mathrm{kV}$ is higher than that for $V_{c}=6 \mathrm{kV}$. This is because the voltages are expressed in per unt. They are nearly equal when converted to kilovolts. The transient voltage acruss the SMES coll has two components as already mentioned. The first component is caused by the forced zero of current through the d.c. cfrcuit breaker and the second component by the residual voltage in the counterpulse capacltor bank, $C$. The negative peak belongs to the first component, and the pusitive peak belongs to the second component. 


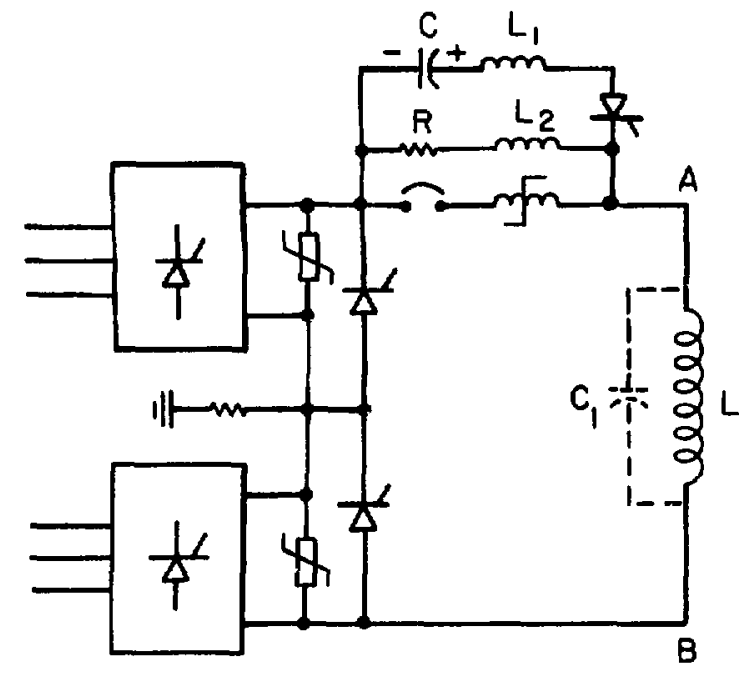

Fig. 4. Schematic of the protective dump circuit of the $30 \mathrm{MJ}$ SMES system. $L=\operatorname{coll}, C_{1}=$ capacitance across coll, $C=$ counterpulse capacitor bank, $L_{1}=$ waveshaping inductor for counterpulse clrcult, $R=d$ ump resistor, $L_{2}=$ self-inductance of $R$.

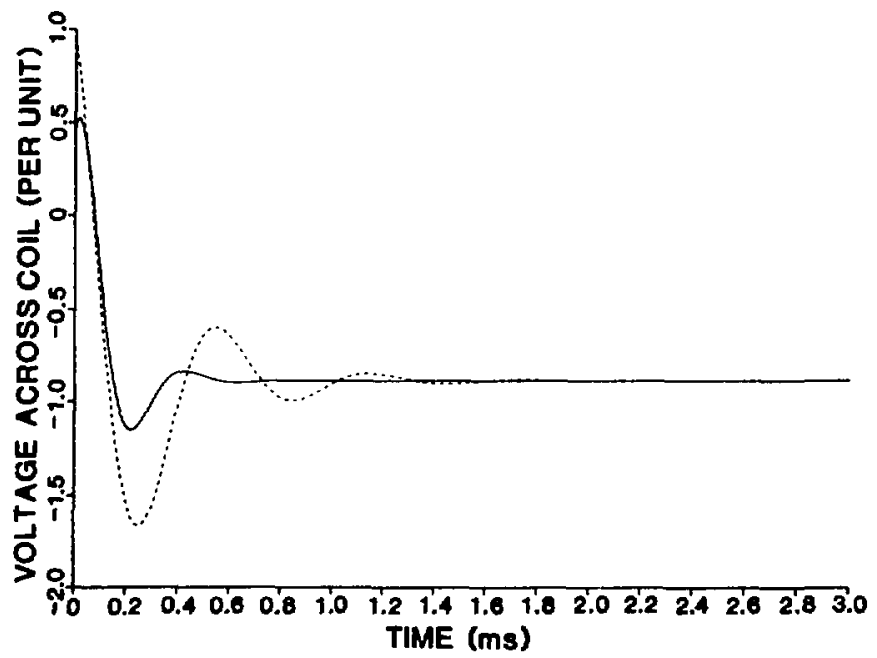

F1g. 5. Transient voltage across SMES col1 caused by current interruption by d.c. circult breaker; effect of dump resistor self-inductance. $v_{c}=5 \mathrm{kV}, \quad I_{L}=4.9 \mathrm{kA}, \quad \mathrm{L}=2.6 \mathrm{H}, \mathrm{L}_{1}=36 \mu \mathrm{H}, \mathrm{C}=60 \mu \mathrm{F}, \mathrm{C}_{1}=0$, $R^{c}=0.9 \Omega$. Solid curve $L_{2}=20 \mu \mathrm{H}$. Dotted curve $L_{2}=100 \mu \mathrm{H}$. Per untt voltage $=$ counterpulse capacitor precharge voltage, $v_{c}$. 


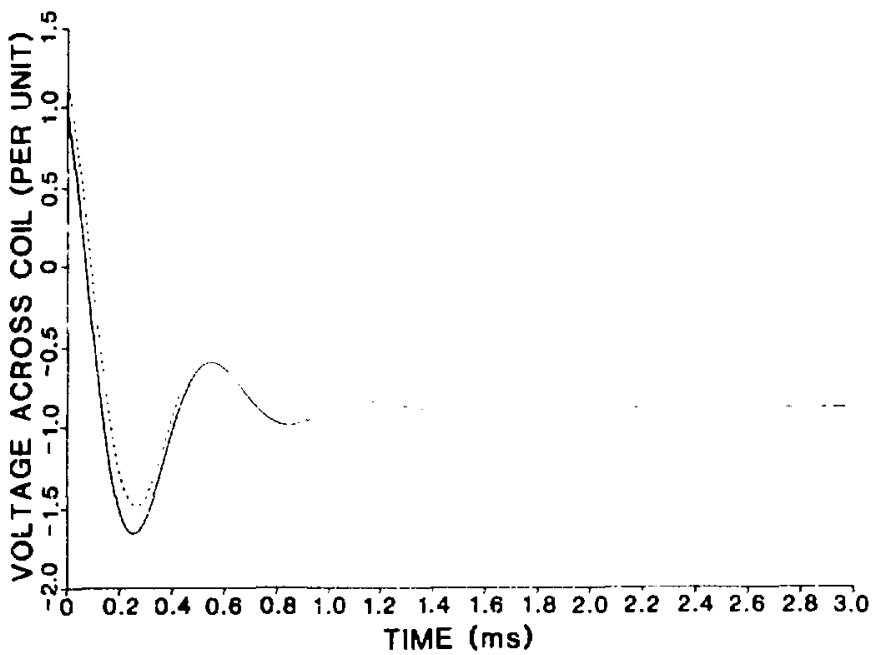

F1g. 6. Transient voltage across SMES coll caused by current interruption by d.c. circult breaker; effect of precharge voltage level of counterpulse capacitor. $\mathrm{I}_{\mathrm{L}}=4.9 \mathrm{kA}, \mathrm{L}=2.6 \mathrm{H}, \quad \mathrm{L}_{1}=36 \mathrm{\mu H}$, $\mathrm{L}_{2}=100 \mu \mathrm{H}, \mathrm{C}=60 \mu \mathrm{F}, C_{1}=0, \mathrm{R}=0.9 \Omega$. Solld curve $\mathrm{V}_{\mathrm{C}}=5 \mathrm{kV}$. Dotted curve $v_{c}=6 \mathrm{kV}$. Per unit voltage = counterpulse capecitor precharge voltage, $v_{c}$.

Figure 7 shows the effect of capacitance across the SMES coll. A capacitance across the SMES coll would produce oscillations. Thest oscillations are accentuated when the self-1nductance, $L_{2}$, of the dump resistor, $R$, is higher. This a1so would produce a higher peak voltage. The beneficlal effect of $C_{1}$ is to reduce the slope of the front but not the amplitude of the positive peak as shown In Figs. 5 and 7. A steep front of the transient voltage could produce highly nonuniform voltage division within the coll with the possibility of turn to turn dielectric failure in the coll. The capacitor, $\mathrm{C}_{1}$, may also be used to modify the frequency components of the switching surge, so that these frequencies are not coincident with the natural frequencies of the coil; otherwise, internal overvoltages would be developed by resonant oscillations. A surge arrester to $11 \mathrm{mit}$ voltage surge across the coll and capable of dissipating $30 \mathrm{MJ}$ of energy of the SMES col1, would be impractical. An alternate approach would be to connect a stack of nonlinear resistors with low internal inductance across the dump resistor. The nonlinear resistors must be designed so most of the $30 \mathrm{MJ}$ stored energy would be dissipated in the dump resistor and would conduct only when the transient voltage exceeds $7.5 \mathrm{kV}$.

An RFQ for a surge protector was sent to several manufacturers who responded negatively. A surge protector will be designed from standard nonlinear resistors. 


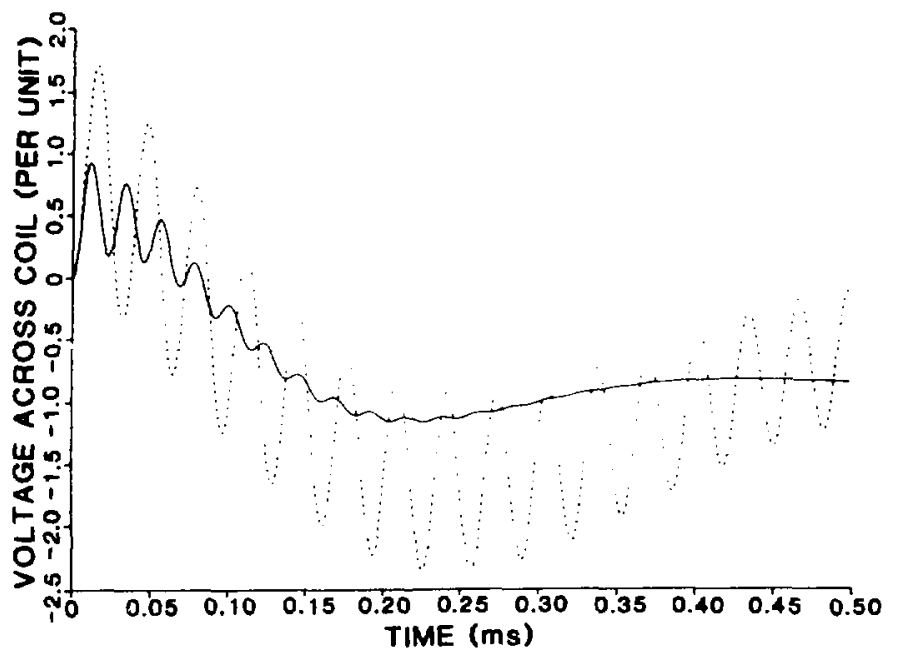

Fig. 7. Translent voltage across SMES coll causer by current Interruption by d.c. circult breaker; effect of capacitance across coll. $V_{c}=5 \mathrm{kV}$, $\mathrm{I}_{\mathrm{L}}=4.9 \mathrm{kA}, \mathrm{L}=2.6 \mathrm{H}, \mathrm{L}_{1}=36 \mu \mathrm{H}, \mathrm{C}=60 \mu \mathrm{F}, C_{1}=1 \mu \mathrm{F}, \quad \mathrm{R}^{\mathrm{C}}=0.9 \Omega$. Solid curve $\mathrm{L}_{2}=20 \mu \mathrm{H}$. Dotted curve $\mathrm{L}_{2}=100 \mu \mathrm{H}$. Per unit voltage= counterpulse capacttor precharge voltage, $v_{c}$.

The natural frequencles of the multiple pancake coll are determined by considering the coll as a lumped network as shown In Fig. 8. Once the coll has been divided into an N-section ladder network, it can be solved by the state variable method. Thus,

$$
\begin{aligned}
\mathrm{dX} / \mathrm{dt} & =\mathrm{AX} \cdot \mathrm{BV}, \\
\mathrm{U} & =\mathrm{SX}+\mathrm{DV},
\end{aligned}
$$

where $X(t)$

$x(t)=$ state vector,

$U(t) \quad$ output vector of node voltages,

$V(t) \quad=$ applied voltage, and

$A, B, D$, and $S=$ matrices of constant coefficients.

The elgenvalues of the matrix $A$ are the natural frequenctes of the coll. The output voltage at each node of the network can also be obtalned for any type of applied voltage. 


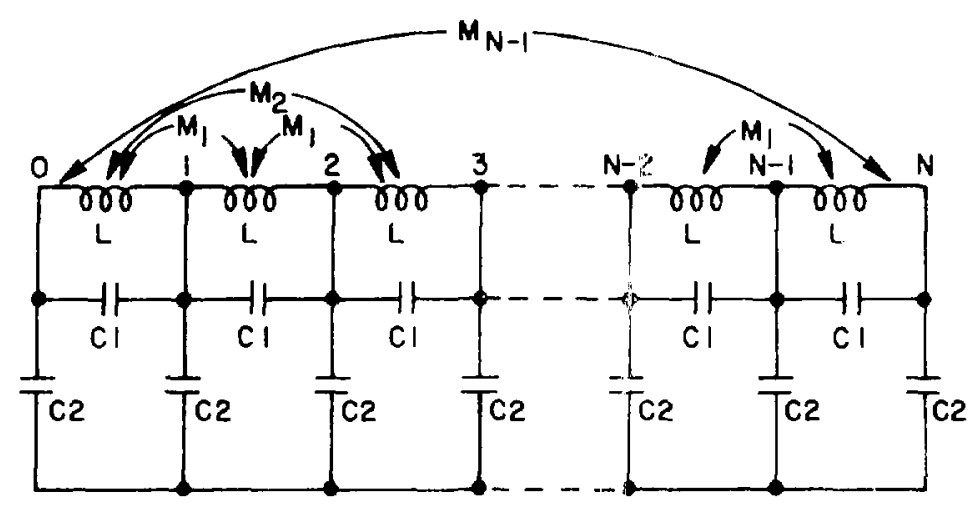

Fig. 8. Schematic representation of a coll as a lumped circutt.

The various capacitances, such as turnto turn, pancake to pancake, and coil to return lead, were calculated. Cylindrlal symmetry or parallel plate configuration was assumed, and different dielettric constants were included for the coll structure materlals. The total serles capacitance, $C_{S}$, of the coll was determined from the following equation to evaluate Eqs. 1 and 2 .

$$
C_{s}=2 C_{e} C_{e}^{\prime} /\left[4 C_{e}+\left(N_{p}-2\right) C_{e}^{\prime}\right] \text {, }
$$

where $C_{e}, C_{e}^{\prime}=c_{p}[1+(\operatorname{coth}(n+1) \theta)(\operatorname{coth}(\theta / 2))]$,

$$
\theta=\cosh ^{-1}\left(1+k / c_{t}\right) \text {, }
$$

$k=2 c_{p}$ for $C_{e}$,

$k=c_{p}$ for $C_{e}^{\prime}$,

$c_{p}=$ capacitance between two corresponding turns on neighboring pancakes, and

$c_{t}=$ capacitances between two nelghboring turns within a pancake.

TABLF II

CALCULATED RESONANT FREQUENCIES OF $30 \mathrm{MJ}$ COIL

Insulating Dewar $\quad \frac{\begin{array}{c}\text { First Harmonic } \\ \mathrm{kHz}\end{array}}{8.8} \quad \frac{\begin{array}{c}\text { Second Harmonic } \\ \mathrm{kHz}\end{array}}{15.8}$


Table II shows the first two calculated space harmunics of the 30 MJ coll. The resonant frequencles of the SMES coll were also measured at room temperature In air without a dewar by two methods. For both methods, a variable frequency sinusuldal volrage source was connected across the coll. The applied voltage and the coll current were observed on an oscllloscope during the first method of test. The cull current showed maxima at resonant frequencles. The voltages at the $1 / 4,1 / 2$, and $3 / 4$ points along the coll were measured during the second method. The midpoint of the coll showed a maxima at the first space harmonic. The $1 / 4$ and $3 / 4$ points showed maxima at the second space harmonic.

The first two space harmonics were measured at about $7.3 \mathrm{kHz}$ and $15.3 \mathrm{kHz}$ when the voltages at $1 / 4,1 / 2$, and $3 / 4$ points of the coll were measured. However, no resonances were detected at these frequencles when the coll current was measured with a $10 \Omega$ resistor. Both methods of measurement gave strong evidence of resonance again at about $335 \mathrm{kHz}$ and $607 \mathrm{kHz}$.

H. Control and Data Acquisition System (Brown, Criscuolo, Cummings, Seamons, a11 $\mathrm{E}-8$ )

The Contrul and Data Acquisition (CDA) subsystem will function as the central communications point of the SMES system. The CDA system will respond to commands from BPA, or a local operator, by adjusting SMES system control parameters and will determine the system's state by monitoring data from each of the subsystems.

The tasks required of the CDA system will be divided among three LSI 11-23 computers from Digital Equipment Corporation. The organization of the CDA system is 11lustrated in the CDA system block diagram of Fig. 9 from the 1980 annual progress report and briefly reviewed here for clarity.

The controller, the supervisory computer and its resources, will function as the central communications polnt and superviaor for the CDA systam and will accept information which describes the desired state for the SMES system from BPA or the local operator. The instantaneous state of SMES will be described by the information from the Cryogenic Data Acquisition System (CDAS) and the Energy Data Acquisition System (EDAS), also referred to as slave computers. After comparing the information from these sources, the controller adjusts the control parameters to bring SMES to the new state being requested. The controller will also display the state information to the local operator and BPA.

The state of the SMES system will be continually monitored by the CDAS and EDAS. These subsystems are capable of acquiring data at a high rate and storing this data for post fallure examination. Attaining a high data rate is the primary reason for separating the control function from the monitoring function. The CDAS and EDAS will be responsible for reporting parameter $11 \mathrm{mit}$ excursions to the controller. The 1981 work report follows.

The resources avallable to the supervisor computer and the slave computers are shown in Figs. 10 and 11 , respectively. This hardware and the SMES system control software will provide

a. Unmanned control of the system for extended perlods of time of weeks to months, 


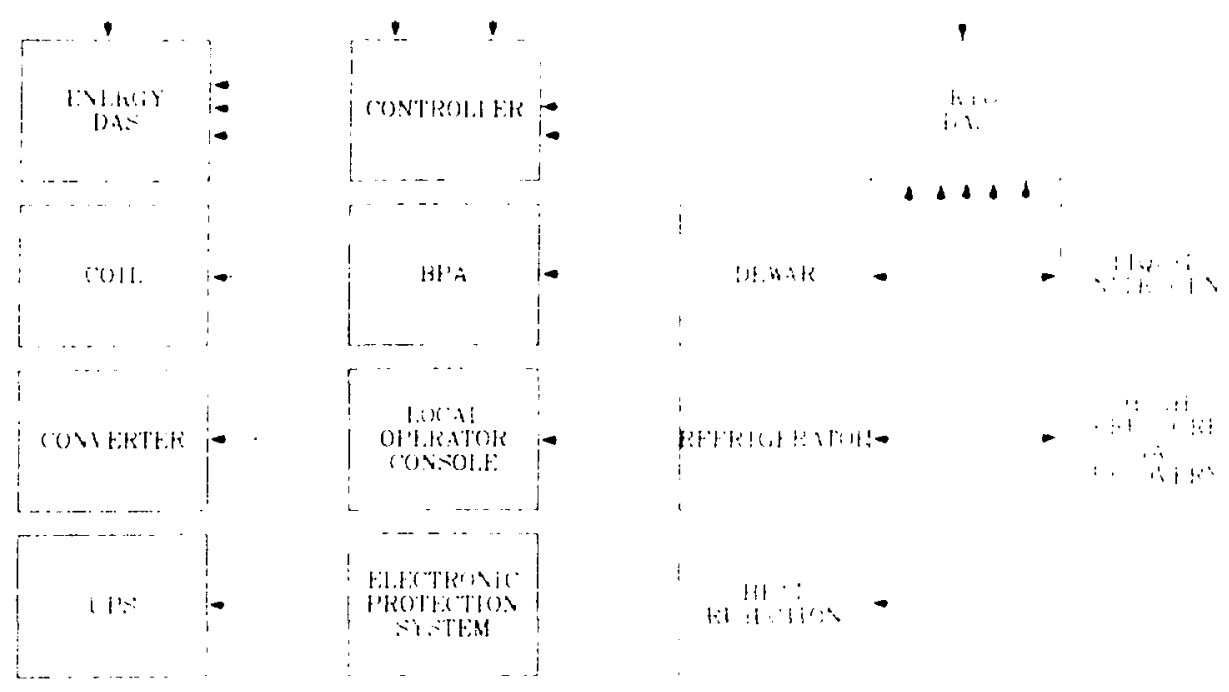

Fig. 9. Contrul and data acquisttion system bluck diagran.

b. Data storage that $h^{\prime} 11$ aid in analyzing sustem perfijrnance and diagnosing system fauits,

c. Display system performance in a manner that facilitates system operations and malntenance, and

d. Safe and rellable shutdown of the system during emergency conditions.

The major accomplishments in the SMES CDA subsystem include (1) operation of several SMES subsystems from the supervisory computer, (2) complet ion of control spectfications for several subsystems, (3) modification of control circuits in several subsystems to increase the effectiveness of computer contrul, (4) completion of the design for the supervisory suftware structure, (5) completions of the design, coding, and check of the a.c.-d.c. converter control software with the hardware, (6) completion of the design, coding, and check of the operator display software with the hardware, (7) design and coding of the control software for the high pressure gas recovery subsystem, (8) completion of the software executed by the slave computers, and (9) change of operating system from RT-11 to RSX-11M. Each accomplishment is described below.

The a.c.-d.c. converter, heat rejection, high pressure gas recovery, and portions of the refrigerator subsystems have been operated through the supervisory and slave computers. This accomplishment provides verification for the system cabling, signal conditioners, computer hardware, many programs in the supervisory and slave computers, and the supervisor data base.

Control speciftcations for the a.c.-d.c. converter, heat rejection, high pressure gas recovery, and BPA interface subsystems have been completed. These specifications include a description of the subsystem functions, detailed flow 


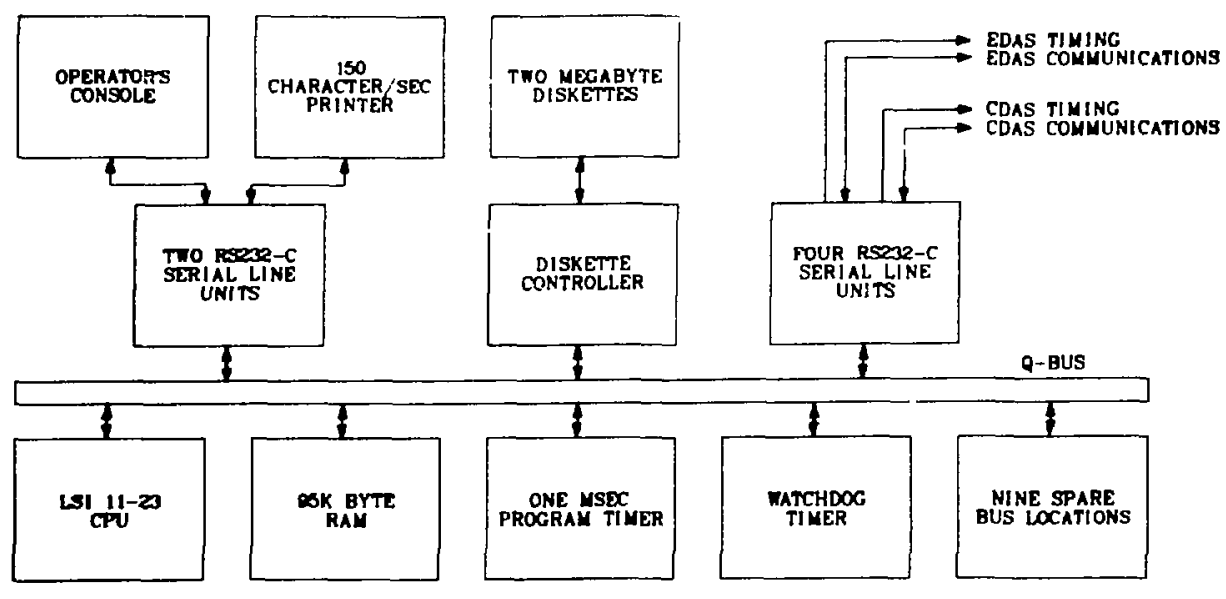

Fig. 10. Supervisory computer resources.

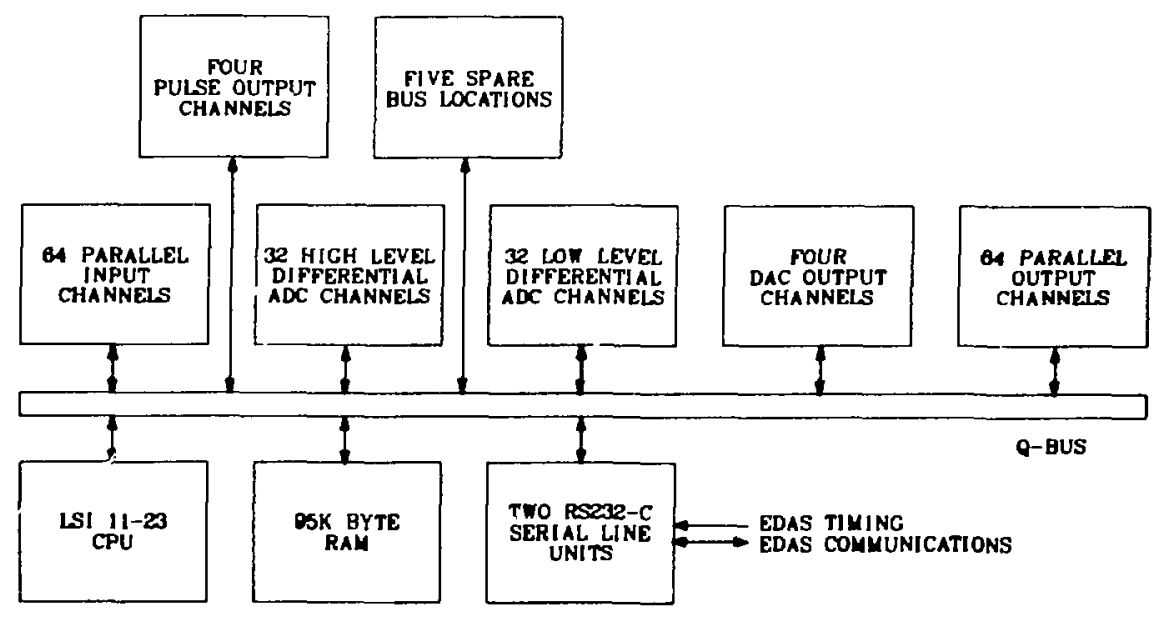

Fig. 11. Slave computer resources. 
charts defining the control sequence for the subsystem, definttion of each interface signal, and wire lists with computer channel assignments for each signal. The speciflcations constitute the basle document from which the contrul software may be generated.

The a.c.-d.c. converter, heat rejectlon, and high pressure gas recovery subsystems required modification of some control circults to allow a smooth transition from manual to computer control and to provide mure reliable computer control. These mudifications have been iompleted. The refrigerator subsystem will require simflar modifications.

Before the supervisory software structure design accomplishment is described, the following intruductury remarks are useful. The supervisory computer has many programs that are executed at variuus times. These programs may be concelved as existing at different levels in a software hierarchy. The highest level is uccupled by the operating system that is supplied by the computer manufacturer. The next level is occupled by a supervisury program that has been designed by the laburatury mintomputer group. The lowest level is occupled by the prograins that are specific to the applicatiun. These programs are designed by the minicomputer group in conjunction with the SMF.S project team members.

In the SMES system the highest level of software is the RSX-IIM operating system. This system pruvides many functions that are generaliy used, including editors, program language compilers, memory management, file management, task priority management, and sharing of the central prucessur. Inltially, RT-ll was the operating system used in SMES but has been replaced by $R S X-11 M$, which has mise capablitties to offer the SMES application.

The supervisory prugram second level suftware was deslgned and coded and is in the early stages of debugging. Tasks that have heen checked in the supervisory program include communications between the supervisury computer and slave computers, operator display, keyboard communications, printer, and data base modification. The principle task that remains to be checked is the communication and courdination with the application programs.

The contrul of the a.c.-d.c. converter thruugh the computer has been completed. The converter has been brought from an unpowered state to an operating state by an operator interacting with the computer. The computer responds to the operator comnands and monitors converter interiocks and set points. The converter output has also foilowed a simulated BPA power demand signal through the computer.

The operator interfaces with the entire SMES system thruugh the console. The console contains a typewriter keyboard and a video screen. The operator enters commands and requests status by typing speciflc character strings. The computer verifies that the commands are correct and approprlate before execution. The readiness of all SMES subsystems is discernable on the video display. The operator may obtain detalled status on each subsystem by requesting that the display be dedicated to that subsystem. Features such as Inverse video, bilnking, and high brightness are used to accent data points that are abnormal. The program that manages the display is operational. 
The slave computer software is completed and operating. This software allows the slave to comunleate with the supervisory computer, acquire analog and binary data from the SMES subsystems, set analog and binary control points, maintain the real time clock, and store data in the translent buffer. The slaves have been operating for several munths with no apparent $3 \cdot \mathrm{s}$ tware problems.

I. BPA S1te Installation

1. Health, Safety, and Envirunmental Remark. (Turner, BPA staff) Consideration was given to environmental concerns for the $30 \mathrm{MJ}$ SMES system to be installed at the RPA Tacoma Substation. A conclusion was reached that the environmental effect is quite 1 imited and the matter was treated in a document entfled "Health, Safety, and Environmental Remark for the $30 \mathrm{MJ}$ Superconducting Magnetic Energy Storage Installation at the Bonneville Power Administration Tacoma Substation, Tacoma, Washington."

2. Dewar and $30 \mathrm{MJ}$ Coll Foundation. (Henke, Schermer; E1lard, ENG-2; BPA staff) Detalled construction drawings were made for the dewar and $30 \mathrm{MJ}$ coll foundation for the Tacoma Substation installation. The drawings were reviewed by BPA and revised to meet their recommendations. See Sec. II.D of this report for more information.

3. Computer Control Interface. (Boenig; Brown, Criscuolo, Cummings, E-8; BPA staff) The 30 MJ SMES system will be computer controlled through a microwave link from the BPA Portland, OR area control and dispatch center to the Tacoma Substation. The contrul description for the interface subsystem between the Los Alamos computer system and the BPA mlcrowave-computer terminal at the substation was completed and sent to BPA for review.

4. SMES Installation Schedule. (Rogers, BPA staff, DOE staff) Meetings were held a BPA Portland, OR and DOE Washington, DC to schedule the installation and operation of the $30 \mathrm{MJ}$ SMES system at the Tacoma Substation. BPA has agreed to alter their research and develupment program and fund commltment to accommodate the installation of the system in FY 82 and to accomplish a11 experlmental and Los Alamos observed ut1lity operations in FY 83 prior to a BPA deciston to accept the system on a permanent basis. The schedule follows and is quite sensitive to early FY 82 adequate funding for Los Alamos.

Activity

Tacoma site preparation complete

Shipment and installation at Tacoma started

Installation at Tacoma complete

Experimental operation started

Utility operation started

Decision for permanent acceeptance of SMES system
Date

$$
\text { 6- } 1-82
$$

6- 1-82

10- 1-82

10- 1-82

2- 1-83

9-15-83 


\section{SUPERCONDUCTOR APPLICATION VAR (SAVAR) CONTROL (Boenig, Rogers, Westinghouse staff)}

Westinghouse Electric Corpuration delivered the final reports of the SAVAR converter design and cost comparison study of the coll optimization study. A Los Alamos report describing the experimental SAVAR test results was completed. These three reports represent the extent of the SAVAR work. DOE was advised to discontinue funding for the SAVAR program because the economic position of a SAVAR unit compared to a conventional static VAR system appears marginal. Further, to establish a reasonable competitive position would require unusual superconductivity technology advances as reported last year. SAVAR program funds were diverted to the SMES program. Anticipated continuing improvements in thyristor ratings and expected increases in energy cost are possible factors that might give additional economic benefits to SAVAR in the future.

IV. SUPERCONDUCTING FAUTT CURRENT LIMITER (SFCL) (Buenig, Chowdhuri, Rogers, Schermer, Weldon, Wollan)

The Power Electronlcs Laboratory of Westinghouse Research and Development Center approached

Los Alamos to cooperate with them on the development of a superconducting current 1imfter for a.c. transmission systems. The Westinghouse circuit was analyzed and a prototype current limiter with a room temperature coll was tested in the laboratory and found to function as predicted.

Several possibie circuit improvements have been examined. One possibility would be the replacement of the superconducting coll by a saturable reactor. The reactor core is premagnetized by a control current in the control winding. The no fault blas current of the blas winding puts the operating point at the knee of the $B=f(H)$ curve. When the fault current through the bias winding increases, the reactor becomes unsaturated and $11 \mathrm{mits}$ the fault current. The saturable reactor is to accomplish two objectives, namely, low losses during non-fault conditions and high impedance during fault conditions. This device is not too unlike a superconducting limiter devised by the British. Another possibility, to replace the diodes in the Westinghouse circuit by SCRs, shows promfse as a solfd state circult breaker with current 1 imfting characteristics. For this clrcuit, a smaller coll and a disconnect switch instead of a breaker can be used. If the SCR version of the current 1 imiter is used, then the mechanical breaker is replaced by a rellable all solld state breaker. All these technical advantages must be weighed against the installation and operating cost of a more conventional current 11miter.

The possibility of using a superconducting fault current limiter in electric arc furnace plants is being investigated. Contacts with three arc furnace plants in E1 Paso, TX; Pueblo, Co; and Stirling, IL were made. The current limiter inserted in the primary side of the furnace transformer could reduce short clrcult current, reduce graphite electrode consumption, extend the IIfe span of the main furnace breaker by reducing the frequency of breaker action, prevent electrode breakage, and reduce loss of operation time. 
An economic and technologisal evaluation of the SFCL was completed. Tables III through IX give the results of that study. Table $X$ gives the superconductiag wire and cable characteristics. The dlode clrcult is that of Westinghouse and the SCR circuit is the Los Alamos modified circuit.

A study ${ }^{2}$ performed for the Electrlc Power Research Institute (EPRI) by Westinghouse Electric Corporation examined resonant circult fault current IImiters with normal conducting reactors. The EPRI report gives costs in 1978 dollars for a $145 \mathrm{kV}, 300$ MVA current $11 \mathrm{miter}$ which can be compared with the $138 \mathrm{kV}, 287 \mathrm{MVA}$ SFCL of this study. The preferred low loss circults of the EPRI study at $15 \mathrm{kA}$ peak let through curreni followed by steady fault current of $2.8 \mathrm{kA}$ cost from $\$ 850$ to 920 thousand. These same circults cost from $\$ 760$ to 1160 thousand for steady fault currents ranglng from 2 to $4.4 \mathrm{kA}$ after the peak let through current occurs. These 1978 costs should be inflated by 33 to $40 \%$ for comparison with the 1981 amuunts listed in Table IX for the $138 \mathrm{kV}$ clrcults. On this basis the SFCL SCR clrcults cost close to the same ( $33 \%$ factor) or show some real advantage ( $40 \%$ factor).

TABLE III

SFCL COIL PARAMETERS

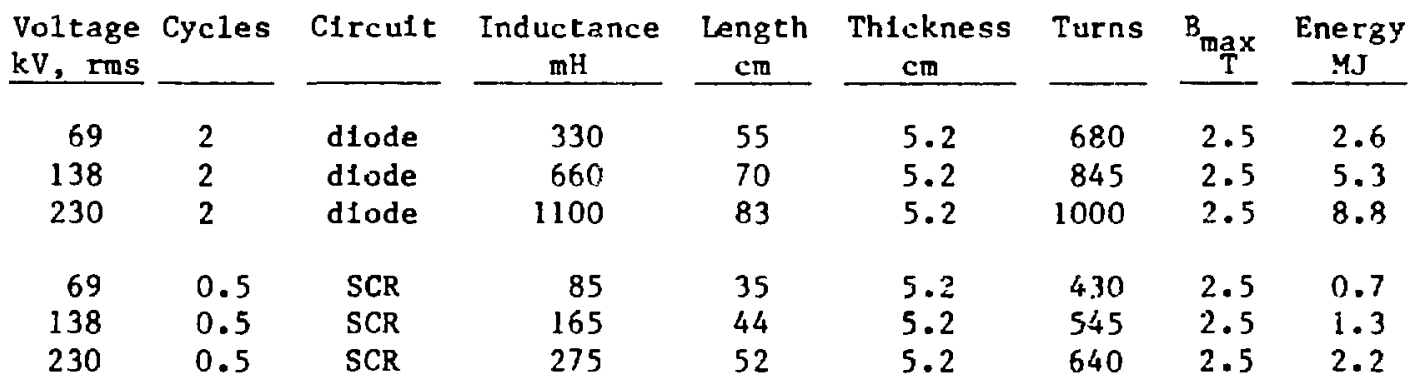

TABLE IV

SFCL COSTS FOR ONE COIL AND CABLE

\begin{tabular}{|c|c|c|c|c|c|c|}
\hline $\begin{array}{l}\text { Voltage } \\
\mathrm{kV}, \text { rms } \\
\end{array}$ & Circuit & $\begin{array}{c}\text { Cable Length } \\
\text { m }\end{array}$ & $\begin{array}{c}\text { Coll Loss } \\
\mathrm{kJ} \\
\end{array}$ & $\begin{array}{l}\text { Cable } \\
\$(10)^{3} \\
\end{array}$ & $\begin{array}{c}\text { Insulation } \\
\$(10)^{3} \\
\end{array}$ & $\begin{array}{l}\operatorname{co1} 1^{a} \\
\$(10)^{3}\end{array}$ \\
\hline $\begin{array}{r}69 \\
138 \\
230\end{array}$ & $\begin{array}{l}\text { diode } \\
\text { dlode } \\
\text { diode }\end{array}$ & $\begin{array}{l}2350 \\
3716 \\
5215\end{array}$ & $\begin{array}{l}12.4 \\
19.6 \\
27.5\end{array}$ & $\begin{array}{l}23.5 \\
37.2 \\
52.2\end{array}$ & $\begin{array}{r}6.8 \\
16.5 \\
31.6\end{array}$ & $\begin{array}{l}147.8 \\
21.3 .6 \\
344.8\end{array}$ \\
\hline $\begin{array}{r}69 \\
138 \\
230\end{array}$ & $\begin{array}{l}\text { SCR } \\
\text { SCR } \\
\text { SCR }\end{array}$ & $\begin{array}{r}946 \\
1507 \\
2091\end{array}$ & $\begin{array}{r}5.0 \\
7.9 \\
11.0\end{array}$ & $\begin{array}{r}9.5 \\
15.1 \\
20.9\end{array}$ & $\begin{array}{r}2.8 \\
6.5 \\
12.4\end{array}$ & $\begin{array}{r}59.8 \\
93.3 \\
129.4\end{array}$ \\
\hline
\end{tabular}

a Includes superconducting cable and insulation. 
TABLF, $V$

POWER ELFCTRONICS PARAMETERS FOR SINGIE PHASE SFCL

\begin{tabular}{|c|c|c|c|c|c|}
\hline $\begin{array}{l}\text { Voltage } \\
\times \mathrm{V}, \text { rms } \\
\end{array}$ & Clrcult & $\begin{array}{c}\text { Arrester } \\
\text { Break-Away } \\
\text { Voltage, kV } \\
\end{array}$ & $\begin{array}{c}\text { Number } \\
\text { Diodes/SCRs }\end{array}$ & $\begin{array}{c}\text { Prutection } \\
\text { Factur }\end{array}$ & $\begin{array}{c}\operatorname{losses}^{a} \\
\mathrm{kw} \\
\end{array}$ \\
\hline 69 & dlude & 75 & 64 & 1.54 & 83 \\
\hline 138 & diode & 150 & 128 & 1.54 & 156 \\
\hline 230 & díde & 190 & 208 & 1.50 & 247 \\
\hline 69 & SCR & 75 & 80 & 1.57 & 143 \\
\hline 138 & $\mathrm{SCK}$ & 150 & lńn & 1.57 & 276 \\
\hline 230 & SCR & 190 & 256 & 1.51 & 435 \\
\hline
\end{tabular}

ancludes $10 \mathrm{kH}$ losses for blas power supply.

TABLF VI

POWER ELECTRONICS COSTS FOR SINGLE PHASE SFCL.

\begin{tabular}{|c|c|c|c|c|c|c|}
\hline $\begin{array}{l}\text { Voltage } \\
\mathrm{kv}, \mathrm{rms}\end{array}$ & Circutt & $\begin{array}{l}\text { Bridge } \\
S(10)^{3}\end{array}$ & $\begin{array}{l}\text { Bias Supply } \\
\quad 5(10)^{3}\end{array}$ & $\begin{array}{l}\text { Arrester } \\
S(10)^{3}\end{array}$ & $\begin{array}{l}\text { Breaker } \\
S(10)^{3}\end{array}$ & $\begin{array}{l}\text { Tutal } \\
S(10)^{3}\end{array}$ \\
\hline 69 & diude & 60 & 25 & 5 & 30 & 120 \\
\hline 138 & diode & 100 & $3 n$ & 8 & 60 & 198 \\
\hline 230 & diude & 180 & 35 & 12 & 100 & 327 \\
\hline 69 & SCR & 100 & 25 & 5 & 10 & 140 \\
\hline 138 & SCR & 160 & 30 & 8 & $2 n$ & 218 \\
\hline 230 & $S C R$ & 290 & 35 & 12 & 33 & 370 \\
\hline
\end{tabular}

TABLF: VII

MYLAR* INSULATION FOR ONE SUPERCONDUCTING COII.

\begin{tabular}{|c|c|c|c|c|c|c|}
\hline \multirow{2}{*}{$\begin{array}{l}\text { Voltage } \\
k v, \text { rms }\end{array}$} & \multirow[t]{2}{*}{ Clrsult } & BIL & \multicolumn{4}{|c|}{ Insulation $\operatorname{Cos} t, s(10)^{3}$} \\
\hline & & $\mathbf{k V}$ & Material & Labor & Shtelds & Total \\
\hline 69 & diode & 350 & 0.6 & 4.2 & 2.0 & 6.8 \\
\hline 138 & díode & 550 & 1.6 & 10.1 & 4.8 & 16.5 \\
\hline 230 & diode & 750 & 3.0 & 19.4 & 9.2 & 31.6 \\
\hline 63 & SCR & 350 & 0.3 & 1.7 & 0.8 & 2.8 \\
\hline 138 & SCR & 550 & 0.6 & 4.0 & 1.9 & 6.5 \\
\hline 230 & SCR & 750 & 1.2 & 7.6 & 3.6 & 12.4 \\
\hline
\end{tabular}


TABLE VIII

DEWAR, BUSHINGS, AND VAPOR COOLED LEADS FOR ONE COIL

\begin{tabular}{|c|c|c|c|c|c|}
\hline \multirow{2}{*}{$\begin{array}{l}\text { Voltage } \\
\text { kV, rms }\end{array}$} & \multirow[t]{2}{*}{ Circule } & \multicolumn{2}{|c|}{ Dewar, $\$(10)^{3}$} & \multirow{2}{*}{$\begin{array}{c}\text { Bushings } \\
\$(10)^{3} \\
\end{array}$} & \multirow{2}{*}{$\begin{array}{l}\text { Leads } \\
\$(10)^{3}\end{array}$} \\
\hline & & Metal & Plast 1c & & \\
\hline $\begin{array}{r}69 \\
138 \\
230\end{array}$ & $\begin{array}{l}\text { dlode } \\
\text { dlode } \\
\text { dlode }\end{array}$ & $\begin{array}{l}10.0 \\
16.0 \\
22.5\end{array}$ & $\begin{array}{l}27.0 \\
43.0 \\
62.0\end{array}$ & $\begin{array}{l}2.0 \\
4.0 \\
6.0\end{array}$ & $\begin{array}{l}40.0 \\
40.0 \\
40.0\end{array}$ \\
\hline $\begin{array}{r}69 \\
138 \\
230\end{array}$ & $\begin{array}{l}\text { SCR } \\
\text { SCR } \\
\text { SCR }\end{array}$ & $\begin{array}{l}5.1) \\
6.5 \\
9.0\end{array}$ & $\begin{array}{l}12.0 \\
18.0 \\
24.0\end{array}$ & $\begin{array}{l}2.0 \\
4.0 \\
6.0\end{array}$ & $\begin{array}{l}40.0 \\
40.0 \\
40.0\end{array}$ \\
\hline
\end{tabular}

TABLE IX

SFCL OVERALL COSTS FOR THREE PHASES

\begin{tabular}{|c|c|c|c|}
\hline $\begin{array}{l}\text { Voltage } \\
\mathrm{kV} \text {, tms } \\
\end{array}$ & Circult & $\frac{\text { Tocal }}{\mathrm{A}}$ & Cost, $\$(10)^{3}$ \\
\hline 69 & dlode & 1134 & 1185 \\
\hline 138 & diode & 1590 & 1670 \\
\hline 230 & dlode & 2396 & 2514 \\
\hline 69 & SCR & 915 & 930 \\
\hline 138 & SCR & 1260 & 1295 \\
\hline $23 n$ & SCR & 1838 & 1883 \\
\hline
\end{tabular}

TABLE $X$

SUPERCONDUCTING WIRE AND CABLE CHARACTERISTICS

W1 re

Dianeter, mam

0.5

Superconductor

NbT1

Number fllaments

1250

Fllament diameter, $\mu$ m

10

Copper to NbTi ratio

Critical current at $4.5 \mathrm{~K}$ and $2.5 \mathrm{~T}, A$

$2.5(10)^{5}$

Critical current density at $4.5 \mathrm{~K}$ and $2.5 \mathrm{~T}, \mathrm{~A} / \mathrm{cm}^{2}$

Cable

F1rst level, $6 \mathrm{Cu}$ around $1 \mathrm{NbT} 1$, soldered

Second level, 16 first level in Rutherford lay

Dimensions, mm 
Full load losses for the fipt resunant ciruclt limiter rated at $145 \mathrm{kV}$ and $300 \mathrm{MVA}$ are $\mathrm{g}$ ven as a function of steady faule curcent at about 0.07 to $0.14 \%$ of the throughput rating. Full load losses, based on Tabie $V$, are 0.16 and $0.29 \%$, respectlvely, for the diode and SCR SFCl, $138 \mathrm{kV}, 287 \mathrm{MVA}$ clreults.

The puwer electrunles of the SCR circults for the SFCl cost 60 to $80 \%$ mure than for the diode circuts. Because the SCK circults permit suppression of the fault current in one-half cycle instead of two, the superconducting colls are smaller and the ciruit breabers are replaced by mueh less costly disconnect switches. The result, sro rable IX, is that the SCR circuits have cust advantages of 79,77 , and $75 \%$, respectively, at 69,138 , and ? $30 \mathrm{kv}$.

\section{MISCELILNEOIS}

A. Superoonducting Colls for HVDC: Transmission lines (Buenig)

HVDC transmisstion lines usually have room temperature reactors connected in each line at each converter station. Theae reacturs serve several purpuses.

1. To recrease harinonle vuilapes and curtents ln the d.e. in ine,

2. To smooth tlie rlpple in the direct current sufficients to prevent: the current frum becoming discontinusus at light load,

3. To ilmit the short circult current, and

4. To prevent commutatiun failure.

These reactors are roum tenneracure reactors and usually have an Inductance of $0 . \therefore$ to $1.0 \mathrm{l}$, although lower inductance reactors have also been used. The steady state curcent tr the $\mathrm{Aac}$. IIne and reactor is on the order of about? kAt and resits in a sured manetic energy of 0.8 to $24 \%$. The suggestion has been made to replace the room temperature reactors by suporconducting colls to reduce the losses af the reacturs. General fiectrli Company, a supplier of Hurb equipient, and several utllties, which operate HVDC lines in the U.S., were contacted tu heternine the eloutrical parameters of existing HVDC 1 ire reactors, especially the losses. The Pacfflc Intertie utllizes reacturs, for example, wth an inductance value nf $0 . i H$ and $810 \mathrm{~kW}$ of losses at rated current. A superconducing coll could reduce the losses conslderabiy.

B. Sys stability Study

The flnial dratt of the Westinghuse Subsynchronuus Resunance Stability study was reviter? and currectlons sent to Westinghuse to oe incorporated in the final report which has been recelved.

C. Static var Cortrul Studies

Study cuntracts for statli reactive power compensators for high voltage power systems with ceneral Fjectric and hestinghouse sere monitored. Satisfactory flanl reports were received from buth companies.

D. Erufesslonal Comittee Wurk

Chowdhuri participaced in the first revision of IEFE standard 518-77, particularly in the uriting of the radio frequency interferences and attended the ANSI Commitcee 63 meeting in Boulder, Co as an IFEF delegate. 
Thullen and Chowdhurl particlpated in a revlew of the geological superconducting survey device at the Richmond Fleld Station of the University of Calffornia to provide consultation on high voltage problems and on deslgn of the supercunducting magnet system. This was done on a reimburstble basis from Exxon, the project sponsor.

\section{PAPERS PRESENTED, PUBLICATIONS, AND REPORTS}

1. H. J. Boen1g, "SAVAR Prututype Experiments," Los Alamus National Laburatury ducument LA-UR-81-591, February 23, 1981 .

2. J. D. Rogers, "Superconducting Magnetic Energy Storage (SMES) Program, January 1 through December 31, 1980," Annual Prugress Report Los Alamus National Laboratory report LA-8777-PR (March 1981).

3. R. I. Schermer, H. J. Boenig, J. Dean, "30 MJ Superconducting Magnetlc Energy Storage for BPA Transmission Line Stabilizer," 7th Internatonal Conference on Magnet Technology, March 30 through April 3, 1981, Karlsruhe, Germany; Los Alamos National Lahoratury document LA-UR-81-939.

4. R. D. Turner, J. D. Rogers, "30 MJ Superconducting Magnetic Energy Sturage for Electric Transmission Stabllization," 16th Intersuciety Energy Conversion--Engineering Conference, August 9-14, 1981, Atlanta, CA; los Alamos National Laboratory ducument LA-UR-81-1535.

5. R. I. Schermer, "30 MJ Superconducttng Magnetlc Energy Storage for BPA Transmission Line Stab1lizer", Mechanlcal, Magnet1c, and Undergruund Energy Storage 1981 Annual Contractors' Revlew, Washingtun, DC, August 24-26, 1981; Los Alamos Nationa1 Laboratory document LA-UR-81-2296.

6. P. Chowdhurl, "Analysis of Switching Surges Generated by Current Interruption in an Energy Storage Coll, 9th Symposium on Englneering Problems of Fusion Research, Chicago, IL, October 26-29, 1981; Los Alamos Nationa1 Laboratory ducument LA-UR-81-3008.

7. R. I. Schermer, "30 MJ Superconducting Magnet1c Energy Storage fur BPA Tranmission Line Stablifzer," Supercunducting Magnetic Energy Sturage Workshop, University of Wisconstn, Madison, WI, October 19-23, 1981; Los Alamos National Laboratory document LA-UR-81-3040.

8. P. Chowdhurf, M. Andersun, "Performance of Large Magnets under Transtent Voltages," Proceedings of the 9 th Sympostum on Fnglneering Problems of Fusion Research, Chlcago, IL, Detober 26-29, 1981; Los Alamos National Laboratory ducument LA-UR-81-3107,

9. H. J. Boenig, R. D. Turner; C. L. Neft, K. H. Sueker, Roblcon Corp., "Design and Testing of a $13.75 \mathrm{MW}$ Converter for a Superconducting Magnetic Fnergy Storage System," 9th Symposium on Englneering Froblems of Fusion Research, Chicago, IL, October 26-29, 1981; Los Alamos National Laboratory document LA-UR-81-3132. 


\section{REFERENCES}

1. K. J. Bathe, "ADINA, A Finite Element Program for Autumatic Dynamic Incremental Nonlinear Analys1s," MIT Dept. of Mech. Fing. report 82448-1, Sept. 1975, Revised Dec. 1, 1978.

2. D. A. Paice, R. P. Putkovich, J. Zubek, J. Bonk, L. Gruve, "Contrulled Impedance Short Circuit Limiter," Electrle Power Research Institute report EPRI EL-857, August 1978. 